\title{
“A Marine Nondescript" Canada's First Icebreaker
}

\section{H.T. Holman}

Le Canada étant une nation nordique, son patrimoine marin a été grandement influencé par les glaces saisonnières qui ont limité l'exploration, la colonisation et le développement du commerce. Si le Canada allait faire amplement appel à des brise-glaces au vingtième siècle, il est étonnant de constater qu'il y avait eu peu de progrès dans ce domaine au cours des années précédentes. Parmi les exceptions, notons le développement dans les années 1870 du Northern Light, un navire à caractère inhabituel qui présentait de nouvelles approches et une conception novatrice. Malheureusement, ces progrès ont été mal appliqués et le manque de succès a fait en sorte que la conception expérimentale a été ignorée ou abandonnée. Cet article examine le début prometteur et la fin peu glorieuse de ce brise-glace innovateur.

Most historians have treated the connections between Prince Edward Island and the mainland as a political subtext to the confederation agreement which changed the Island from a colony to a province. When the communication issue is discussed, it is usually in relation to dominion-provincial relations; however, little attention has been paid to the actual mechanisms surrounding attempts by the dominion to fulfil the communication obligation, which was, for Islanders, one of the key considerations in their decision to become part of Canada. ${ }^{1}$

\footnotetext{
1 The Island's history during the last quarter of the nineteenth century has been the subject of relatively little study. Frank MacKinnon's The Government of Prince Edward Island (Toronto: University of Toronto Press, 1951) still stands out although it is limited to political history. Communications are covered but briefly in Judith Fingard's chapter "The 1880s: Paradoxes of Progress" in E.R. Forbes and D.A. Muise eds. The Atlantic Provinces in Confederation (Fredericton:
} The Northern Mariner / Le marin du nord, XXIX, No. 4 (Winter 2019), 313-334 
The conditions of union included a clause requiring Canada to be responsible for "...Efficient Steam Service for the conveyance of mails and passengers, to be established and maintained between the Island and the mainland of the Dominion, Winter and Summer, thus placing the Island in continuous communication with the Intercolonial Railway and the railway system of the." 2 Usually shortened to "continuous steam communication" this clause would bedevil dominion governments for more than a century. Summer service was relatively simple to achieve, with contracts awarded to the Prince Edward Island Steam Navigation Company, but the promise of winter service across the ice-filled Northumberland Strait taxed the ability of the dominion to do more than simply make a series of best efforts. The asymmetrical expectations of Prince Edward Island and Canada as regards the service provided grounds for political conflict, but they also posed a technological challenge on how best to deal with steamers facing winter ice conditions. This paper explores the development of Canada's first icebreaker and how this technological response, embraced at the outset as a genuine advance, met with failure when faced with the realities of the ice of Northumberland Strait. ${ }^{3}$

While efforts to make ice-bound parts of Canada more accessible for yearround trade have been a continuous issue in the nation's history, surprisingly little work has been devoted to the early development of the technology which could make it possible. A number of sources examining the evolution of ice breaking in the European context have been published, but work on the history of ice breaking in Canada before 1900 is almost non-existent. ${ }^{4}$

Acadiensis Press, 1993). One of the few studies which examines interprovincial communications in any detail is Mary K. Cullen, "The Transportation Issue 1873-1973" in Francis W.P. Bolger, ed., Canada's Smallest Province: A History of P.E.I. ([Charlottetown]: Prince Edward Island 1973 Centennial Commission, 1973), 232-44. The Northern Light is noted in the context of government marine operations in Thomas G. Appleton's Usque Ad Mare A History of the Canadian Coast Guard and Marine Services (Ottawa: Department of Transport, Queen's Printer, 1968), 53-59. Cross-Strait communication also was a consideration in railway development in the area. See, for example, Dean Jobb, "The Politics of the New Brunswick and Prince Edward Railway, 1872-1886," Acadiensis, 13:2 (Spring, 1984), 69. Retrieved from https://journals.lib.unb.ca/index.php/Acadiensis/article/ view/12226

2 MacKinnon, 357.

3 For purposes of this paper I have used a general description of an icebreaker as a ship possessing three traits most normal ships lack: a strengthened hull, an ice-clearing shape, and the power to push through sea ice.

4 One of the few recent studies, S.J. Jones's article "A history of icebreaking ships,"Journal of Ocean Technology 3: 1 (Spring, 2008), 54-74 makes no mention of the Northern Light or other early Canadian icebreaking vessels. Kim Richard Nossel's chapter "Polar Icebreakers: The Politics of Inertia" in Franklyn Griffiths's Politics of the Northwest Passage, (Montreal and Kingston: McGillQueens Press, 1987) does include the Northern Light in a list of icebreakers at 218 but provides no details of her service. A much earlier study, Robert Runeberg "On Steamers for Winter Navigation and Ice-Breaking," Minutes of the Proceedings of the Institution of Civil Engineers 97: 3 (January,1889), 277-301 details Scandinavian and Finnish vessels up to the time of its publication but he does not appear to have had knowledge of the Northern Light. Likewise, in a table of historical icebreakers in E.C.B. Corlett and G.R. Smith's "Some Aspects of Icebreaker Design," Transactions of the Royal Institute of Naval Architects 1964, 389-413, the Northern Light does not appear. Interestingly the 
An idea born in Québec

The history of Canada's first icebreaker begins with an individual who had an interest, if not an obsession, with the annual accumulation of ice which renders Québec a seasonal port. The period of winter isolation provided a challenge to the development, not only to the port, but to the economy of Upper and Lower Canada. The annual blockage of passage of the St Lawrence River and through the Gulf retarded international trade and was a major concern for the merchants and inhabitants of the city of Québec and beyond.

In the mid-nineteenth century Edmund Willoughby Sewell was living in Lévis and was a close observer of the relationship between Québec and the seasonal ice. Sewell, born in 1825, was well connected to the Québec elite. His grandfather, Jonathan Sewell, had been chief justice of Québec and other relatives also held prominent positions. ${ }^{5}$ By 1847 , E.W. Sewell had established himself as a "ship architect" and alone or in partnership with others, was responsible for the building of at least eighteen sailing vessels, most at shipyards in Lévis. ${ }^{6}$ He was also responsible for the building of a steam powered, paddlewheel tow-boat used in the port of Québec in 1854. Sewell's interest in winter navigation appears to date from at least 1851, when he presented a paper on naval architecture to the Literary and Historical Society of Québec. ${ }^{7}$ The following year, a petition regarding a winter steam ferry was presented to the Québec House of Assembly. This petition credits E.W. Sewell with originating the proposal. ${ }^{8}$

In 1867, the Québec Board of Trade deemed winter navigation on the St Lawrence possible, but reported that high insurance rates made it impractical. ${ }^{9} \mathrm{~A}$ copy of their report was furnished to imperial authorities and also sent to delegates from the Maritimes, then in London negotiating the terms of Confederation. ${ }^{10}$ In 1874, the Québec Board of Trade held a special meeting to consider Sewell's views

table also fails to mention the British-built Canadian government steamers Stanley and Minto which also were designed as icebreakers for Canadian waters. In Garth Wilson, A History of Shipbuilding and Naval Architecture in Canada (Ottawa: National Museum of Science and Technology, 1994) the first mention of any Canadian icebreaker is J.D. Hazen in 1916.

5 Henry J Morgan. Sketches of Celebrated Canadians and Persons Connected with Canada... . (Quebec: Hunter Rose and Company, 1862), 146. Sewell family history pages found at http://www. robertsewell.ca/sewell.html and at https://www.sewellgenealogy.com/p550.htm\#i1075 accessed 17 February 2019.

6 Sewell did not have his own yard but used those of others in his shipbuilding activity. Eileen Reid Marcil, "Shipbuilding at Quebec 1763-1893: The Square Rigger Trade" ( PhD thesis, Laval University, 1987), 116, 190.

7 Report of the Council of the Literary and Historical Society of Quebec for the year ending $14^{\text {th }}$ January 1852. http://www.pakobrats.com/morrin/virtualLibrary/docsfromclient/books/343/343.html accessed 17 February 2019

8 James McPherson Le Moine, Quebec, Past and Present, A History of Quebec 1608-1876 (Quebec, 1876), 432, https://babel.hathitrust.org/cgi/pt?id=hvd.32044081320590\&view=1up\&seq $=5$ accessed 18 February 2019.

9 Chicago Tribune, 4 January 1867.

10 Ottawa Daily Citizen, 26 February 1867. 
on winter navigation on the River and Gulf of St Lawrence. The board passed resolutions supporting the initiative and calling on the dominion government to "grant such encouragement to Mr. Sewell as will enable him to thoroughly test this important question." "In August of that year, Sewell published a paper which concluded that "steamers... would never come into contact with the ice to such an extent as would seriously impede their progress." 12

Late in 1874, Sewell and others presented a petition to the Québec Legislative Assembly requesting aid to encourage winter navigation. ${ }^{13}$ A select committee of the legislature was established to review the possibilities for winter navigation on the lower St Lawrence. In mid-February1875, the committee reported on a number of related matters, including the form of vessel best suited to deal with the ice, the navigational difficulties from snow and fog in the absence of aids to navigation, and the best routes to be followed to reduce exposure to ice. Along with pilots, the Québec harbour master, and a hydrographic engineer, the committee also heard from Edmund W. Sewell. The committee optimistically concluded that although it would not be possible to employ sailing vessels during the winter months, "Winter Navigation could not be arrested at any time by the ice flow" and that "floating ice which moves with the ebb and flow of the tides could not impede the progress of a well constructed screw steamer." 14 The committee pointed to the fact that winter operation of the ferry service between Québec and Lévis, which had long been held to be impossible, had been in regular service since 1869 . They also observed that the dominion government had undertaken to maintain winter navigation across Northumberland Strait - an undertaking it had not yet accomplished. For the committee, successful winter navigation would have broad implications: "If modern science can be enlisted in the accomplishment of the object sought, Canada would then possess the inestimable advantages of an independent and uninterrupted communication by water with Foreign Countries and a great portion of her own people living on both shores of the St Lawrence." 15

Although the committee took evidence on "form and structure of the vessel best adapted to encounter and overcome the floating ice," it appears that Sewell was the only one to present comments on this aspect, and then in only the vaguest of terms. The chief design problem he addressed was the exposure of the crew to severe weather conditions. According to Sewell, this would be not a problem as the spar deck would cover the vessel fore and aft and would also be heated with steam pipes. This would also keep equipment such as the rudder chains from freezing up. ${ }^{16}$ The phrase "properly constructed steamer" appears throughout the evidence

\footnotetext{
$11 \quad$ New York Times, 11 November 1874.

12 Canada, House of Commons Debates 3rd Parl 3rd Sess, (9 March 1876), (Louis Honoré Fréchette).

13 An approach was also made to the dominion government. It was discussed in the Privy Council and referred to the minister of Marine and Fisheries but no action was taken. Canada, Privy Council Orders in Council 1874-1467 3 December 1874.

14 Quebec, Journal of the Legislative Assembly, 38 Victoria, 221.

15 Ibid., 223.

16 Quebec, Select Committee of the Legislative Assembly Quebec on the Winter Navigation of the
} 
but without explanation or detail.

Through 1875, Sewell's activities in regard to winter navigation increased. In January, speaking before the Dominion Board of Trade, it was reported that "He was so thoroughly convinced of the feasibility of navigating the St Lawrence in the winter, that he and his associates were quite willing to run vessels up and down the St Lawrence, and not ask a single cent from the Government, until they had demonstrated, by actual experiment, that the river could be navigated at all seasons." 17 In March, he was in Ottawa promoting the idea of winter navigation and displayed a model of a screw steamer. Although proposed for the St Lawrence River, the model was inspected with great interest by members of Parliament from the Maritimes. ${ }^{18}$ The Montreal Herald reported on Sewell's proposal and although indicating a level of scepticism, it noted that the assistance requested seemed low in comparison with the value of a successful outcome. "We can imagine no improvement of the same magnitude which can be bought at the same price." 19 That month a report appeared in the British journal Engineering, stating that Sewell was having a steamer built for the purpose of testing his ideas on winter navigation. ${ }^{20}$ In April of 1875 he spoke to the Literary and Historical Society of Québec on "The Winter Navigation of the St Lawrence." 21

By that time, the idea of a "well-constructed" steamer capable of navigating in ice was moving from the theoretical to the practical. Le Journal de Québec reported in late January that Sewell had begun construction of a special steamboat which would come into service for the winter of 1875-1876. ${ }^{22}$ In May the English journal Engineering carried an article from the Ottawa Free Press reporting details of the steamer then under construction in Sewell's shipyard in Levis:

The Steamer Northern Light now building in the yard of Mr. E.W. Sewell at Levis, and intended to test the winter navigation of the Gulf and River St Lawrence, is a vessel of great speed and power. She is of the following dimensions: length on deck 154 feet; depth of hold $14 \mathrm{ft} .9$ in.; breadth of beam 24 feet. She is to be fitted with a compound engine of 700 horsepower indicated. The diameter of the screw, $12 \mathrm{ft} .6$ in. with a pitch of $20 \mathrm{feet}$; boiler $11 \mathrm{ft}$. by $14 \mathrm{ft}$. made of the best 7/8 in. iron, fitted with

\footnotetext{
River and Gulf St Lawrence, Report, [1875], 28.

17 Dominion Board of Trade, Proceedings of the Fifth Annual Meeting, (Montreal, 1875), 151.

18 Ottawa Daily Citizen, 6 March 1875.

19 Montreal Herald and Daily Commercial Gazette, 23 March 1875 At the time of the report the proposal was for funding of $\$ 14,000$ per year for five years, payable only on a successful result each year.

20 Engineering, 12 March 1875, 214.

${ }^{21}$ Index of the Letters, Papers and Historical Documents Published by the Literary and Historical Society of Quebec: and also of the names of their authors together with a list of the unpublished papers read before the society 1829 to 1891 (Quebec, 1891) http://www.pakobrats.com/morrin/ virtualLibrary/docsfromclient/books/343/343.html.

${ }^{22}$ Le Journal de Québec, 25 January 1875.
} 
condenser, and carrying $105 \mathrm{lb}$. of steam. This vessel is so formed that no right angle pressure can be brought to bear by ice in any part of the hull, thus reducing the resistance to a minimum. The keel runs with a graceful curve (something in the form of a skate) to the foot of the stern, which is so shaped as to continue the sweep above the line of greatest immersion, thus enabling the vessel to separate or displace the ice at three points, viz. underneath and on the port and starboard sides of the bow. All these provisions on the part of the builder and designer show great forethought and study. For a height of $2 \mathrm{ft}$. above the line of floatation and a depth of $1 \mathrm{ft}$. below the Northern Light is to be plated with iron plates of $4 \mathrm{in}$. by $3 / 8$ in. iron. She is to be fitted with a spar deck, on which is to be built the wheel house, well forward. This house will be fitted with double plate glass and heated by the exhaust steam, passing through iron piping, which will be fitted in all those portions of the vessel where heat is required. She will carry a fore and aft foresail, mainsail and fore staysail and will steam 17 miles an hour in smooth water. ${ }^{23}$

In March 1876, the House of Commons debated winter navigation on the $\mathrm{St}$ Lawrence. Louis Honoré Fréchette, the Liberal MP for Lévis, moved for the appointment of a select committee on winter navigation on the St Lawrence River and Gulf. He asserted that the matter was of national importance and identified E.W. Sewell as the "projector of the scheme," noting that a Quebec parliamentary commission had already examined the question and issued a report in 1875 from which he quoted at length. Sewell had also made a proposal to the dominion government for a subsidy of $\$ 16,000$ per year for five years to prove the practical experience of an ice steamer. Although not all members of the House were in favour of Sewell's financial proposal, they did agree to set up the committee to study the matter of winter navigation. ${ }^{24}$

The committee moved with unusual haste. They interviewed only four witnesses: Sewell, two sea captains, and a Pictou shipbuilder. Committee members expressed regret that distance from the capital and exceptionally severe weather had prevented other competent witnesses from appearing. They also incorporated the findings and evidence of the 1875 report from the Québec Legislative Assembly. Sewell presented a report and also appears to have shown the committee a model of a proposed vessel which would demonstrate ice navigation, but he conceded that the vessel was too small for commercial purposes. When asked if a larger ship would have to conform to the design of the model to be successful, he stated that the small vessel "has been so formed so as to reduce the ice pressure to a minimum, whereas the large steamers of the usual form, from their superior weight and power, would pass through the floe-ice with facility." 25

\footnotetext{
23 Engineering, 21 May 1875.

24 Canada, House of Commons Debates, (9 March 1876).

25 Canada, Journals of the House of Commons 1876, Appendix 4, 4.
} 
In less than a month, Fréchette's select committee returned to the House with its report. Notwithstanding the enthusiasm of the witnesses and the report's strong endorsement of the beneficial results of year-round steamer traffic, the final recommendation of the committee was cautious. It recommended "...that steps be taken towards a practical demonstration of this important theory as soon as the financial position of the country will admit." ${ }^{26}$ At that time, however, the financial position of the dominion did not admit, and there was little follow-up on the St Lawrence proposal. Undaunted, Sewell continued to publicize his ideas and to seek support for this proposal and others. ${ }^{27}$

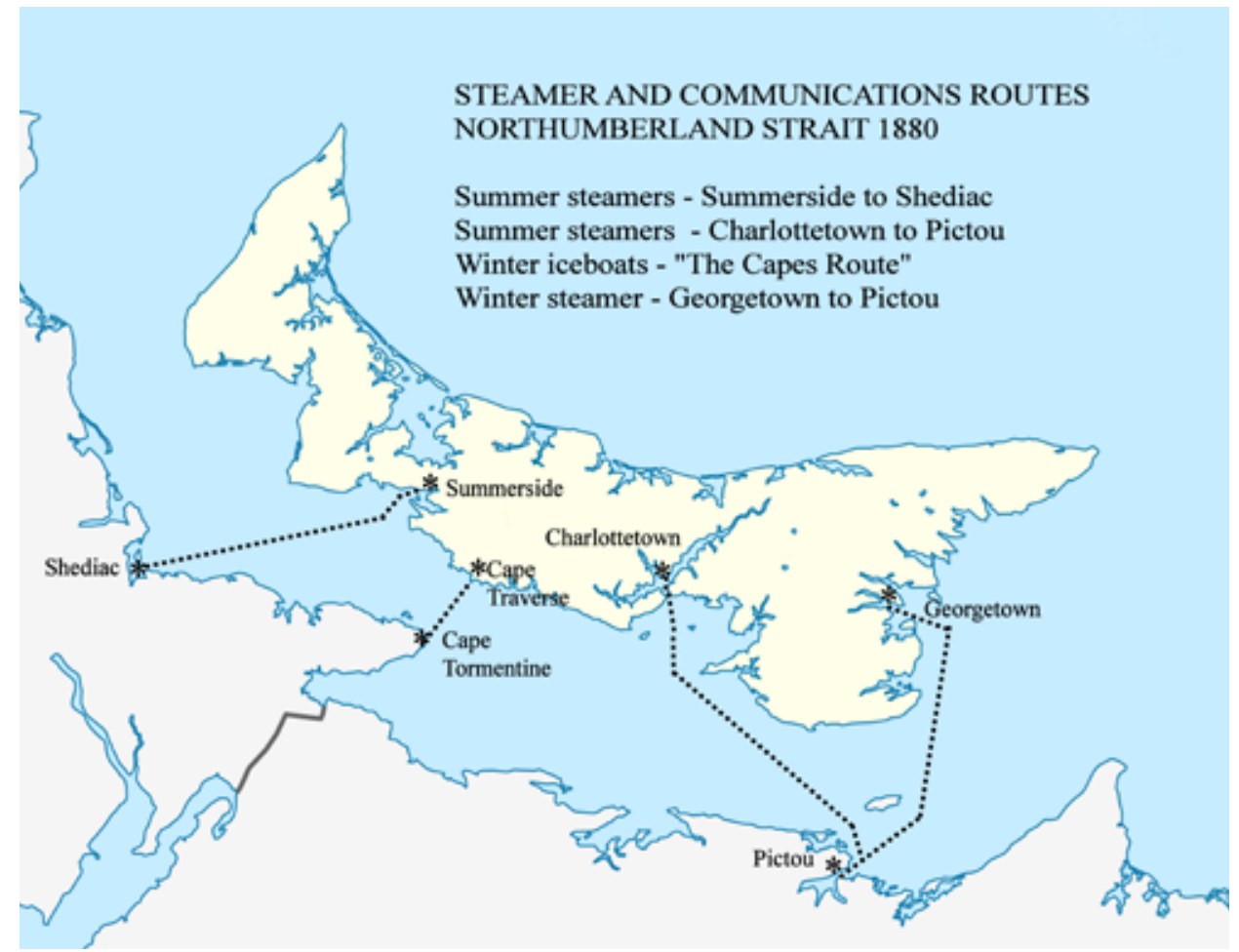

\section{Moving the question}

In the meantime, developments elsewhere in the country shifted the government's attention from winter navigation from the St Lawrence to a more pressing problem: the commitment to "continuous steam communication" with Prince Edward Island. The completion of the Prince Edward Island Railway following Confederation meant that the three main ports of the province (Summerside, Charlottetown and

26 Ibid., 2.

27 In November 1875, for example, Sewell told the Lévis Chamber of Commerce that he had made a proposal for the St Lawrence Navigation Company's steamer Progress to provide year-round service between Québec and a number of Northumberland Strait ports. Morning Chronicle and Commercial and Shipping Gazette, 22 November 1875, 2. 
Georgetown) were linked by rail. On the mainland, rail service had reached Shediac via a wharf at Pointe du Chêne in 1860. This enabled connections with Saint John and, after the completion of the Intercolonial Line in 1876, with Québec. Pictou had rail service with Halifax as early as 1867 and was also linked with the Intercolonial rail system at Truro. The Prince Edward Island Steam Navigation Company had regular seasonal steamers from Summerside to Shediac and from Charlottetown to Pictou. These services were closed when ice set in, usually from early December until April. During the winter, communications between PEI and the mainland consisted exclusively of an iceboat service carrying mails and passengers across the narrowest part of Northumberland Strait between Cape Traverse and Cape Tormentine, the so-called "Capes Route." Georgetown, in the eastern part of the Island, was normally the last harbour to experience ice closure but it was rarely used by the regular steamers.

The attempt to fulfill the Confederation commitment of continuous communication had itself become somewhat jammed in the ice. A contracted steamer, the Albert, which had no specific ice capability, had utterly failed to deliver the anticipated service during the winter of 1874-75. George Howlan, speaking in the Canadian Senate in April 1875, referenced Sewell's model in the context of continuous communication. In the opinion of the Islanders who had seen it, Sewell's proposed vessel "would more completely meet the necessities" and Howlan challenged the government to move quickly to end the contract with the Albert and find a new boat. ${ }^{28}$

In a parliamentary debate which took place in Ottawa at the end of February 1876, Prince Edward Island MP David Laird observed that Sewell already had a winter steamer under construction and in 1875 had offered it to the dominion government for Northumberland Strait service, but on condition that breakwaters be built at Cape Traverse and Cape Tormentine. This condition had not been acceptable to the government. Accordingly, a second round of tenders was called for a service between Georgetown and Pictou. An offer from the Prince Edward Island Steam Navigation Company was accepted, but the company was then unable to find an acceptable vessel. ${ }^{29}$ Having failed to find a contractor to take on the task, the government elected to undertake the service themselves. What was needed was a suitable vessel. Island MP Daniel Davies later wrote of the selection process:

Mr. James Yeo and myself, being shipbuilders and interested in steamers, were supposed by the Island representatives to be the best qualified to select a boat suitable for the service - if it could be got. After examination of the model, plans, specifications, etc. of the "Northern Light," and getting all the information we could from persons who had some experience in

28 Canada, Debates of the Senate, 3rd Parl, 2nd Sess, (3 April 1875), 673-674.

29 The company offered to supply a "British built spar decked steamer of not less than one hundred and fifty feet long ... specially adapted for the service," crossing the Strait "whenever practicable." Canada, Privy Council Orders in Council 1876-0045 19 January 1876. 
"Icy Navigation," we recommended the Minister of Marine and Fisheries to purchase her, and our recommendation was acted on. She was not such a boat as we would have selected if there had been any choice..$^{30}$

Their preference had been for a Clyde-built steamer specially designed for the route, but the additional time required to develop plans and construct such a vessel was deemed unacceptable.

In April 1875 a $\$ 50,000$ contract was signed with Sewell for construction of a winter steamer, and by 10 April work was already underway (or, more likely, had resumed) at the Lévis shipyard. The vessel under construction was the one which Sewell had previously described, when he had appeared before the Commons committee, as too small for commercial purposes. At any rate, the time to complete the vessel was remarkably short, and launch took place on 6 September. ${ }^{31}$ Final fitting out continued through the fall of 1876, and on 4 December the vessel was dispatched to Charlottetown. ${ }^{32}$

\section{A vessel of peculiar model}

The ship which made its way down the St Lawrence in early December was a very different ship from any previously seen in Canadian waters. An 1877 New York Herald description called it "A Marine Nondescript," ${ }^{33}$ i.e., something not easily described or classified, being neither one thing nor another. The term "icebreaker" had yet to come into common usage.

As a nation with a frozen coastline and interior waterways, Canada had long experience with ships and ice. Early explorers quickly learned the necessity of having vessels which could survive the crushing forces of ice. However these early, ice-reinforced ships were designed to be frozen into the ice rather than move through it. Ice navigation was an impossible dream in wind-powered or paddlewheel vessels, but the advent of the screw propeller provided opportunities to experiment.

The first true icebreaker was the Russian steamer Pilot, which was adapted in 1864 to include a rounded shape and sloping bow. This allowed the ship to push itself up onto the ice, crushing it with its weight. The ship was used in the Gulf of Finland to extend the shipping season by several weeks. In the late 1870s, the

\footnotetext{
30 Daily Examiner (Charlottetown), 19 February 1884, letter from Daniel Davies.

31 Morning Chronicle and Shipping Gazette (Québec), 7 September 1876. The Québec newspaper referenced Sewell's "earnestness and dogged perseverance" in what they saw as the first step in the resolution of the question of winter navigation on the St Lawrence. Interest in the project was also noted in British newspapers, a large number of which mentioned the launch including the Merthyr Telegraph and General Advertiser for the Iron Districts of South Wales, 29 September 1876. The short accounts were not entirely accurate; the Merthyr account suggested that the vessel was constructed to make voyages down the St Lawrence to Prince Edward Island.

32 Daily Examiner (Charlottetown), 16 October 1876; Canada, House of Commons Sessional Papers No. 5, "Annual Report of the Department of Marine and Fisheries for 1876," xxvi.

33 New York Herald, 16 March 1877.
} 
design had been adopted by other European countries for rivers and coastal waters. What distinguished the Northern Light from the early Scandinavian and Finnish designs is that the European vessels were primarily concerned with harbour, river and estuary operations, while Sewell's ship was to be used for open water routes with large moving floes of ice.

There is no direct evidence that Sewell was aware of the European ice vessel developments, but Québec was a port that greeted vessels from all over the world and he may well have learned of innovations being tried elsewhere. ${ }^{34}$ In addition, one of the witnesses for the 1875 Québec hearings on winter navigation was Colonel J.C. Farijana, identified as a hydrographic engineer who had been employed by the Russian government on the Baltic Sea. ${ }^{35}$ It is probable he would have been aware of developments there with regard to ice navigation.

The design of the Northern Light was certainly a departure from contemporary marine architecture. Her registration provides the bare statistics of her size, but articles in such journals as Scientific American and Engineering, and in newspapers in Canada, the United States and the United Kingdom show there was a great deal of interest in this odd vessel and how she would deal with the ice. ${ }^{36}$ One of the more detailed accounts is from the New York Herald:

The Northern Light is a vessel of peculiar model. The steamer is 144 feet long, 25 foot beam, with a draught of water of 17 feet at the stern and about 3 feet at the bow. She has an exceedingly sharp floor and a high bilge, the latter being at the line of flotation, thus reducing the ice pressure to a minimum and preventing anything like a right angle pressure. The shape of the bottom secures the vessel from any disastrous pressure when caught in the piling floes and enables the steamer to enter or work out of harbors with facility. Her draught of water being as above stated there is secured four feet of water above upper blade of the propeller which is twelve feet in diameter, with a pitch of 18 feet 6 inches. The keel is formed with a gentle sweep or curve resembling somewhat the iron of a skate, which unites with the curve of the stern so gradually that it is difficult to say where the latter joins the keel. The peculiar shape enables the vessel to ride over and depress the ice, her forward draught 14 feet back of the

\footnotetext{
34 Eileen Reid Marcil points to a number of examples of what she called the unshackled innovative spirit of the shipbuilders. "Unshackled, but informed, for though Québec was far from shipbuilding centres in Britain and the United States, the builders were well-aware of developments in shipbuilding technology. Not only did hundreds of shipmasters visit the port each year bringing news of them, but shipwrights arriving from different countries and different areas of those countries, from merchant and from naval shipyards, helped to keep the discussion fresh." Marcil, 492.

35 Quebec, Legislative Assembly, Select Committee on the Winter Navigation of the River and Gulf St Lawrence, Report, [1875]; Engineering, 30 April 1875, 374. The name is cited as Col. Tarigana in Canada, House of Commons Debates, (20 March 1878).

36 Scientific American, 24 March 1877,177; Engineering, 21 May 1875, 436 (quoting the Ottawa Free Press).
} 
stem being only 8 feet. During summer navigation she is trimmed to draw but 2 feet forward. This is to prevent her falling off in a sea way. The skin of her hull is double, the outer covering being a two and a half inch thickness of greenheart, a species of wood that is as hard as lignum vitae, and for the purpose better than iron. The whole is enclosed so that in the water the steamer resembles a metallic coffin with bull's-eyes in the sides to afford light and air. The interior is warmed by exhaust steam, and thus greatest comfort in the most inclement weather is secured. The engines are of compound build, and are of 700 horse power. The cylinders are side by side their diameters being 60 and 30 inches. The boilers, two in number, are circular, 11 feet in diameter and 9 feet long. There are three furnaces. The test pressure on the steam gauge is 140 pounds, the working pressure about 70 pounds, and the consumption of coal 13 tons per 24 hours. An idea of the power of this vessel may be had from the fact that she has steamed into Georgetown harbor through ice twelve inch thickness at the rate of seven miles an hour for a distance of four miles and a half, and has split ice thirty-six inches thick as far as the eye could reach with one blow of her fore foot, and hummock ice from ten to fifteen feet thick. Her stem for several feet is solid. The crew consists of twenty men, and there are pleasant accommodations for forty passengers. ${ }^{37}$

No photographs of the ship are known to exist, but illustrations of the ship were widely published and show a vessel with a swept back bow and an enclosed spar deck perforated by small ports. Invariably depicted smashing through ice floes at speed, the Northern Light had a distinctive profile. Several of the sketches show a cross section of the vessel - much like a child's spinning top with a deep keel and rounded shoulders which supposedly demonstrated the ship's ability to resist the pressures of the surrounding ice. ${ }^{38}$

\section{The Northern Light is dimmed}

The Northern Light arrived in Charlottetown on 7 December 1876, but her early performance was not promising. It seems the entire population, and especially the politicians and newspaper editors, were watching closely. ${ }^{39}$ The local agent for the Department of Marine and Fisheries later reported that the vessel had arrived "not

\footnotetext{
37 New York Herald, 16 March 1877.

38 The most accurate image is from the Canadian Illustrated News, 2 December 1876, 328, which credits the illustration to a sketch by E.W. Sewell. The same image appeared in L'Opinion Publique, 14 December 1876, 570. Other images appeared in L'Opinion Publique, 1 March 1877, 99; Picturesque Canada 1882, 854, Frank Leslie's Popular Monthly 24 (1887), 184; Harpers Weekly, 21 February 1885, 117; S.G.W. Benjamin, "The Cruise of the Alice May," Century Magazine 27 (18831884), 548.

39 The Examiner was especially critical of the Northern Light's performance, printing an editorial and three letters mocking the ability of her ability to perform on her first voyage. Daily Examiner (Charlottetown), 25 December 1876, 2.
} 


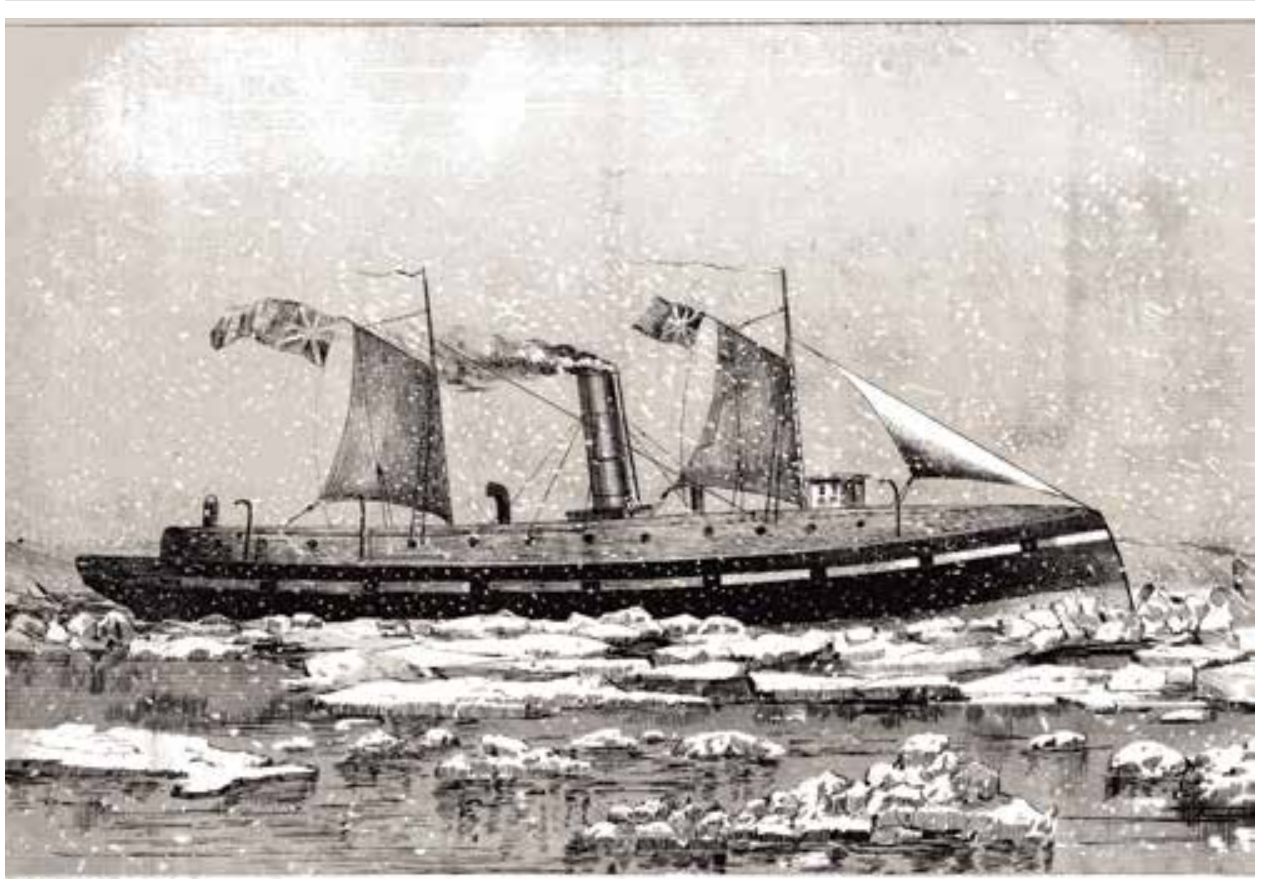

Northern Light (detail) from a sketch by Edmund Sewell. Canadian Illustrated News (2 December 1876), 328.

at all in a fit state to encounter the heavy ice." 40 She left for Pictou six days later and ran, with difficulty, through light ice at Charlottetown Harbour. Her steering gear failed as she approached the Nova Scotia port and she went aground on Pictou bar. ${ }^{41}$ She reached the wharf with the assistance of a tug and she arrived back in Charlottetown on 14 December. A report dated 20 December said that ship had failed to rise up and crush the ice, but instead wedged herself in and managed to break only two or three feet of each ice with each attempt. ${ }^{42}$ The Northern Light left Charlottetown for Georgetown on Christmas Day, but cold weather and high winds had thickened drift ice and it took ten days to reach port, with much of the time spent stuck in the ice. On learning of the issues, the government accepted Sewell's offer to proceed to the Island in order to "rescue this vessel from its humiliating position." "43 Sewell immediately set out for Prince Edward Island and told the Chignecto Post in Sackville that the shortcomings were the work of "incompetent" men; he wanted to have the ship surveyed for damages. Ironically, he was delayed at Cape Tormentine while waiting for a chance to cross the ice to the Island by ice-boat. ${ }^{44}$

40 Annual report of the Department of Marine and Fisheries for 1877. Canada, House of Commons Sessional Papers No. 1 Appendix 36, 366.

41 Daily Examiner (Charlottetown), 18 December 1876.

42 Morning Chronicle and Shipping Gazette (Québec), 21 December 1876, 2.

43 Morning Chronicle and Shipping Gazette (Québec), 29 December 1876.

44 Chignecto Post (Sackville), 4 January 1877. 
Through the 1876-77 season, the Northern Light managed to make about ten round-trip passages a month. During February, owing to ice jams, she frequently had to moor at the board ice which was firmly attached to the land and refuel and transfer passengers and freight across the ice by sleds. As conditions improved in March and April, she was able to make a number of same-day return trips in a little as four hours in each direction. ${ }^{45}$

The first detailed eye-witness account of the crossing of the Strait in the Northern Light appeared in the New York Tribune and was dated 1 February 1877. In the overblown style of the period, the author records impressions of the dramatic battle with the ice:

The helmsman with impassive face kept her straight on her course and we braced ourselves for a shock which never came. The bows grated harshly on the breaking ice and rose into the air as the inclined plane of the keel pressed more and more upon the floe. The field beside us sank, and behind us vast pieces of tons of weight came up from the depths splashing and whirling in our wake, while before us, just as we almost lost headway, a long crack suddenly opened, and shoving the debris to either side the noble vessel glided easily along into an area filled with huge masses of heavier ice.

Slowly we forged in between two masses as large as the boat herself, and surrounded by scores of others of varying weight and so closely packed that then hope of forcing a way through would seem utterly baseless. The armored wedge like bow glided in, the small crevice widened; almost imperceptibly afar off we saw the floes swing and separate, and pushing like a bull the boat squeezed through into thinner ice to repeat the process again and again in a single mile of progress. ${ }^{46}$

Journalistic enthusiasm could not, however, mask the severity of the conditions faced by the Northern Light. The first passage saw significant injury to the vessel, including damage to the iron cutwater armouring the bow, which was torn from the ship by the ice. ${ }^{47}$

It was not just the Northern Light's inability to cut through the ice that was found wanting. Accommodation for passengers and the capacity for freight seem to have been secondary considerations in Sewell's design. The Examiner reported that she had accommodation for only twenty-eight passengers and 500 barrels of freight. ${ }^{48}$ The ship may simply have been too small for the task to which it had been set. In a Commons debate in 1883 Island MP Edward Hackett told the House

\footnotetext{
45 An indication of the degree of interest in the new service comes from the fact that the departmental Annual Report noted above contains a complete listing of trips and dates from the captain's log book.

46 Times-Picayune (New Orleans), 1 March 1877 quoting from the New York Tribune.

47 Ibid.

48 “Light at Last," Daily Examiner (Charlottetown), 11 December 1876.
} 
that Sewell advised the minister of Marine and Fisheries at the time of contract discussions in 1876 that the Northern Light was "too light and too short" and required lengthening by twenty feet, but the minister would not consent to the alteration to the design. ${ }^{49}$

After the 1876-77 winter season, the vessel underwent internal and external alterations. The passenger saloon was increased in size, staterooms were enlarged and made more comfortable, scuttle lights were installed to give more light and air, and a new heating system installed. A ladies' cabin was created and the men's quarters were also made more comfortable. On the spar deck, a new wheel house

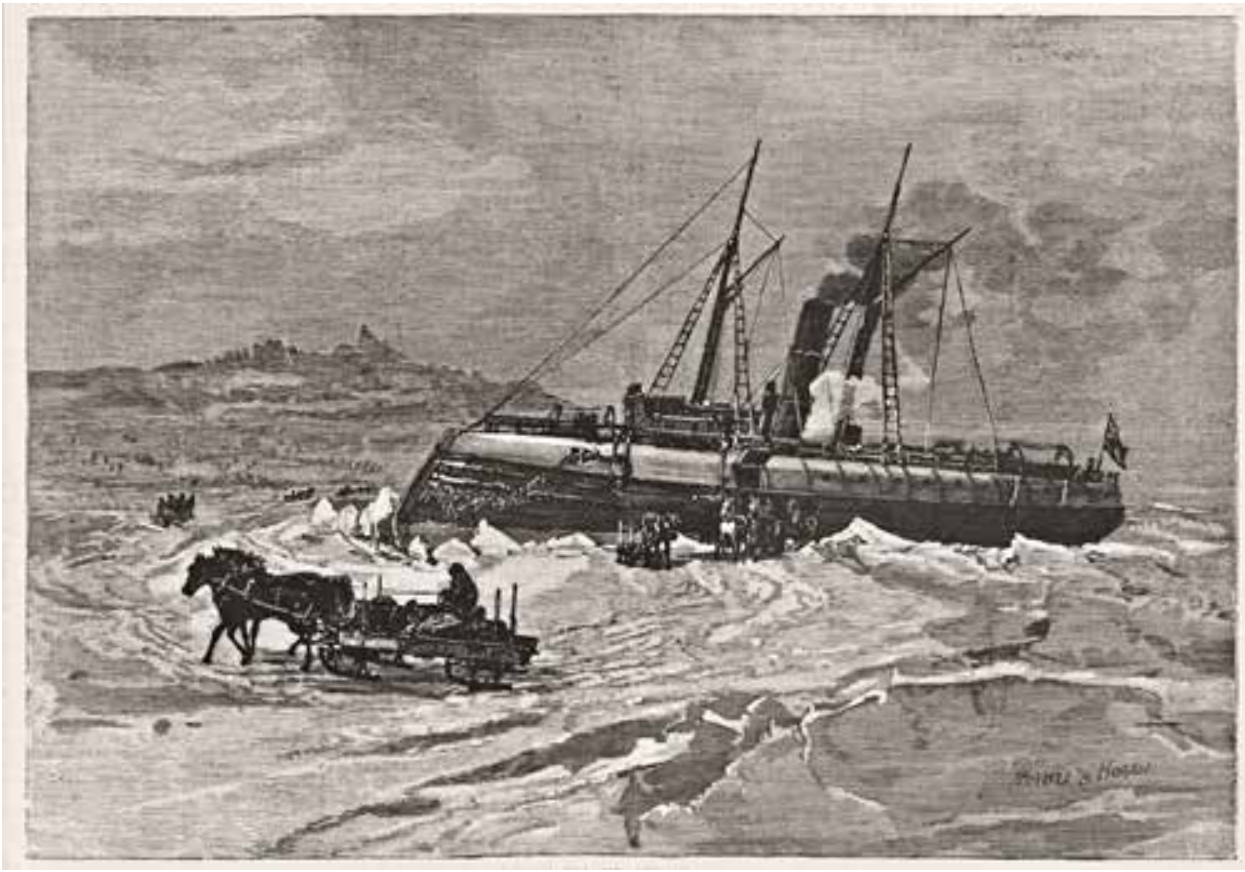

"A metallic coffin with bull's eyes in the sides." Northern Light from Harper's Weekly (21 February 1885), 117.

and captain's quarters with improved steam heating were built and a new covered entrance to the saloon was created. ${ }^{50}$ The ship was also strengthened with a new stem of live oak which was cased in $3 \frac{1}{2}$ inch iron plating where it met the ice. The forward section of the hull was plated with $3 / 4$ inch iron and an inch-thick shoe was added to the entire length of the keel. Additional timber and iron knees were added and four new cross beams installed amidships. ${ }^{51}$ These changes and improvements brought the cost of the vessel up to $\$ 60,000 .^{52}$

49 Daily Examiner (Charlottetown), 27 February 1883.

50 However, without an overall increase in the size of the vessel more passenger accommodation must have been at the expense of the freight capacity.

51 “The Northern Light," The Patriot (Charlottetown), 22 November 1877.

52 Canada, House of Commons, Sessional Papers No. 1, "Annual Report of the Department of 
While the 1876-77 winter service might be characterized as experimental, the following year gave a better test of the vessel's capacity. Her season began following the usual withdrawal of the summer boats of the Prince Edward Island Steam Navigation Company in early December. The first crossing from Georgetown to Pictou took place on 19 December, followed by successful crossings until 25 January 1878 , when continual north-east winds sent heavy and rafted drift ice into the eastern part of Northumberland Strait. This made navigation for the Northern Light difficult, if not impossible, for a period of almost three months. Sewell had been on board as a consultant for at least one voyage in January and fought bitterly with the captain and crew. He left on 11 January, telegraphing the minister that the "ignorance and prejudice" of the crew would not justify his staying aboard. ${ }^{53}$ When he returned to Lévis he wrote to the minister of Marine, noting that "the enterprise is not in good hands" and offering to take charge of the vessel until May on condition that he take his own engineer and mate. The offer was declined..$^{54}$ On the 10 April the Northern Light broke her propeller, which prevented any further trips for the season. She had made only thirty-one round trips between Georgetown and Pictou and was kept in port for forty-four days over the course of the season. ${ }^{55}$

The winter of 1878-79 saw a similar pattern which soon became the norm. Up until mid-January, the Northern Light was able to provide a regular service, but after that, the ice pack in the Strait allowed her to make only occasional trips to Pictou. The reality of irregular and undependable service was underscored by an advertisement that warned that the ship would cross whenever there was a chance and that "Intending passengers had better be in Georgetown, in order to avail themselves of the first opportunity." 56 That year Sewell reiterated his charges that the vessel was being managed in an unsafe manner and further charged that Captain Finlayson had acted as a coward the previous winter in not being more aggressive in the handling of the vessel..$^{57}$ In late February, the Northern Light sustained damage to her shaft bearing while in heavy ice and all further service ceased for the season. In 1878-79, she made only twenty-one round trips and those on a very irregular basis. Once again she spent much of the off-season undergoing repairs and modifications.

One of the points of contention with regard to its effectiveness on the Northumberland Strait service during this period was the charge that the ship was not being operated as it had been designed. In committee hearings in 1883, Senator Carvell dealt with this. He had travelled on the ship with Sewell and testified that

\footnotetext{
Marine and Fisheries for 1877," xxviii.

53 Daily Examiner (Charlottetown), 11 March 1878, 2.

54 Daily Examiner (Charlottetown), 2 March 1878 and 7 March 1878; Gazette (Montreal), 2 March 1878.

55 Canada, House of Commons, Sessional Papers (1879), No. 3, “Annual Report of the Department of Marine and Fisheries for 1878," 126.

56 Daily Examiner (Charlottetown), 18 February 1879. The irregularity of the service was sufficiently notorious that the advertisement did not appear in later years.

57 Montreal Gazette, 24 January 1879.
} 
Sewell's "idea of running the ship was that, [it] should never bump against the ice, that is to stop her. ... with the round fore-foot she has if she struck the ice, instead of it stopping her she would run up on it." He criticized the captain for altering the trim of the vessel so that instead of drawing thirty inches forward, the bow was at a depth of $61 / 2$ or 7 feet, thus thwarting Sewell's design. Sewell believed that the captain was afraid to navigate the ship with the bow high as it would be difficult to manoeuvre in high winds. Carvell related that in some instances she would run so far up on the ice that jack-screws were necessary to get her off. A compounding problem was that the increased weight related to coal requirements to ensure fuel was available for many days in the ice resulted in the vessel being bow-down. In addition, as the limited cargo space was located forward; when large loads of freight were carried the balance of the ship was moved toward the bow and reduced her ability to ride up on the ice. ${ }^{58}$ Carvell stated that while Sewell was aboard, the ship was trimmed to comply with his designs, but after Sewell's return to Québec "She has not been in that trim since."

The terse recital of the number of trips and the days when service was suspended (as found in the Department of Marine and Fisheries Annual Reports) is given a human dimension in an article written by a naval officer, Frank Haslewood. He travelled on the Northern Light in January 1881, accompanied by his pregnant wife and small child. Haslewood and his family were among a group of forty-seven passengers on the ship, which had sleeping accommodation for only eighteen. The Northern Light took twenty-four days to go the forty-six miles between Pictou and Georgetown. The family appear to have been almost the only passengers who stayed on the ship when it was icebound, the others having left at various opportunities on the iceboats which the steamer carried - several suffering severe frostbite on their slow and dangerous crossing of the ice to the Island shore. Reduced to one meal a day as provisions ran low, the few remaining passengers and crew attacked the ice with saws, jack-screws and pinchbars to try and relieve the pressure of the ice on the ship. Haslewood recounts the physical strain on the ship and the mental strain on the passengers and crew that the ice created as it "nipped" the Northern Light.

On the 28th [of January] a movement of the ice caused the ship to be heavily nipped, the field on one side remaining stationary, while that on the other kept pressing against the side. Remembering that the ice was quite a foot thick and was being forced on the ship by the movement of a field extending as far as the eye could reach, some idea may be formed of the strain to which the vessel was subjected. The beams kept up a dismal creaking and bent up in some cases a couple of inches, and the ice cracked

\footnotetext{
58 The inability to change the trim of the ship while underway was identified as a significant design issue and when proposals were called for replacement of the vessel in 1886, moveable ballast was noted as one of the requirements.

59 Canada, Journals of the House of Commons (1883), Appendix 3, 73.
} 
with frequent loud reports, as, unable to force the ship, it gave to the weight behind it and piled in big blocks alongside.

The awful part of this nipping is the feeling of utter helplessness with which you see it. Nothing you can do with any human assistance appears likely to help, and there you stand, watching as calmly as you may the struggle between this natural force and that you have to pit against it; you know either you must give way or the ice must, and you anxiously wonder which it is to be. However, after about an hour of this, the running ceased, the beams gradually resumed their normal positions, and all of us breathed freely once more, thankful to that Providence which had rescued us. ${ }^{60}$

The extent of the damage to the ship during its first years of operation speaks to the stresses to which it was subjected, especially in the winter of 1880-81, when several of the beams and bulkheads were buckled by the pressure of the ice.

In the summer of 1881 repairs included new beams at the stern to counteract the vibration of the propeller, refastening of the beams and knees of the engine room with stronger iron bolts, and fitting of additional knees and beams. An iron beam installed between the boilers and four new beams and knees forward of the boilers were critical additions to strengthen the ability of the hull to resist the ice. The ship was fitted with a new four-bladed bronze propeller, the third propeller in five years. At the same time, improvements were made to the passenger accommodation, including the addition of a heater in the ladies' cabin. ${ }^{61}$ Possibly in response to the hardships experienced by large numbers of passengers who had had to leave the ship while it was stuck in the ice, a limit of thirty passengers per trip was imposed. ${ }^{62}$ However the next season saw another lengthy passage, when passengers once again had to be removed from the ship across the ice owing to lack of provisions. The Northern Light took from 4 February until 21 March to make a round trip from the Island to the mainland. ${ }^{63}$

By the spring of 1883, dissatisfaction with the service had increased to such an extent that a special committee of the House of Commons was appointed to consider the whole question of steam communication with the Island in both summer and winter. The committee's report, with both a record of the testimony

\footnotetext{
${ }^{60}$ Frank Haslewood, "A Voyage on the Northern Light," Murray's Magazine 3: 13 (January, 1888),106-117. Although not written until 1888 and not indicating the date of the trip it clearly describes events of 1881. Navigation Lieutenant Haslewood was an officer in the British Hydrographic Service, then working on the Newfoundland survey, and apparently based in Charlottetown. His wife was newly arrived from Australia and this trip to Prince Edward Island may have been her introduction to the country!

61 Daily Examiner (Charlottetown), 8 November 1881, 3 December 1881 (reprinting a report in the Halifax Herald).

62 Daily Examiner (Charlottetown), 12 December 1881 The limit of thirty passengers per trip seems to have been widely ignored. In 1887 a report in the Acadian newspaper reports double that number with only six cabins available.

63 A lengthy account of part of the trip when the ship was imprisoned in the ice was written by J.G. Moylan, Inspector of Penitentiaries, and appeared in the Ottawa Daily Citizen, 4 March 1882.
} 
and the recommendations, extended to more than one hundred pages. ${ }^{64}$ The committee made a number of recommendations relating to improvement of the winter iceboat service between Cape Tormentine and Cape Traverse. They also warned that the steamers of the Prince Edward Island Steam Navigation Company (which provided the summer service) were nearly twenty years old and were no longer adequate for the increased traffic. They suggested that replacement of at least one of these paddle steamers by a screw steamer could deal with light ice conditions and would extend the shipping season by a few weeks in fall and open it earlier in the spring. Much of the report also dealt with the Northern Light and its suitability as an ice steamer. In the first five years of the service, the ship had been unable to make a crossing on an average of forty-eight days each year, and the winter of 1880-81 featured failures on seventy-two days. The committee concluded that the steamer could not overcome the difficulties of winter navigation, although slight improvements in the design would improve her performance. The committee were unanimous in their conclusion that "no steamship can be built capable of keeping up continuous communication in midwinter between the Island and the Mainland." ${ }^{65}$ Notwithstanding this conclusion, they recommended that the winter service between Georgetown and Pictou be continued, but cautioned that as the Northern Light "was fast becoming unfit for service," another suitable steamer should be provided. ${ }^{66}$

Extensive repairs were again required before the 1884-85 season. The entire stern was found to be suffering from dry rot and had to be replaced. The ship, which had recently received a new hull of five inch planks, was covered with an additional layer of three inch birch planks. Where chafing was experienced on the ice line, the planking was of greenheart. The interior was strengthened and additional knees installed, along with a new keel which was protected with an iron stem plate extending from two feet above the load line right to the stern. The engine and boiler also received a complete overhaul. ${ }^{67}$

The winter of 1886-87 continued the pattern of suspension of service during the period of heaviest ice coverage. The Northern Light operated from 21 December, making twenty-one round trips between Charlottetown, later Georgetown, and Pictou, until 4 February, when she was laid up at Souris. She operated again from 6 April until 5 May, when the summer steamers took over the route. Even this abbreviated schedule was a challenge for passengers. A correspondent for the Wolfville newspaper, The Acadian, wrote that in late April 1887 they had been forced to take a team from Pictou and go six and a half miles to the shore and then four miles in row-boats from the shore to the edge of the ice in order to meet the

\footnotetext{
64 Canada, Journals of the House of Commons 46 Victoria 1883 Appendix No. 3, "Report of the Select Committee appointed by the House of Commons to consider the question of Steam Communication between Prince Edward Island and the Mainland in Winter and Summer."

65 Report of the Select Committee, 1.

66 Report of the Select Committee, 3.

67 Daily Examiner (Charlottetown), 11 December 1884.
} 
steamer, which had been unable to reach Pictou. ${ }^{68}$ During that winter, the dominion had also chartered the steamer Neptune, the largest vessel of the Newfoundland sealing fleet. Originally the sealer was hired to replace the Northern Light, which according to at least one report was soon to be dismantled. However, protests led to a decision that the vessels would run jointly. ${ }^{69}$ It was hoped that the use of the second steamer would provide regular mail and passenger service each way between the Island and the mainland. The cautious Chignecto Post noted that the arrangement was for the winter "or while the harbours are open." ${ }^{70}$ However the Neptune proved to be even less effective in dealing with the ice than the Northern Light, and the experiment was not repeated. ${ }^{71}$ The next year another dominion vessel, the SS Lansdowne, was used in an attempt to reduce the freight backlog, moving from Summerside to Georgetown as ice closed the Prince County harbour. But by the end of December 1887, almost as soon the ice appeared in the Strait, she was pulled off the route and the Northern Light operated alone for another winter. ${ }^{72}$

The question of the winter service was discussed in the dominion cabinet in April 1888. A detailed survey had revealed that both hull and machinery of the Northern Light were not worth further repair. The vessel's limited carrying capacity also made commissioning a new vessel advisable. The minister was authorized to procure a new steel vessel "with all the latest improvements." The direction included specific details for ice navigation including water-tight compartments, ballast tanks to change the trim while in the ice, and engines and boilers able achieve a speed of thirteen or fourteen knots. It was assumed that the vessel would be about 180 feet long, would have a draught of twelve feet, and displace about 700 tons. $^{73}$

Captain McElhinney, who had formerly been an officer on the Northern Light and was described as a nautical advisor to the Department of Marine, was sent to Europe to report on the most suitable type of vessel for the conditions in the Strait. He cited the success of what was described as a Gothenburg icebreaker. A steamer of that design had successfully kept the harbour of the Swedish city open for winter navigation. ${ }^{74}$ By June 1888 a contract had been concluded with Elder and Company of Glasgow for a replacement for the Northern Light. The story

\footnotetext{
68 The Acadian (Wolfville), 6 May 1887.

69 Chignecto Post (Sackville), 23 December 1886.

70 Chignecto Post (Sackville), 30 December 1886.

71 "Annual Report of the Department of Marine and Fisheries," Canada Sessional Papers \# 51888.

72 Daily Examiner (Charlottetown), 27 December 1887, 31 December 1987, 2.

73 Canada, Privy Council Order in Council 1888-0739, approved 10 April 1888.

74 Daily Examiner (Charlottetown), 29 May 1888. The vessel in question was the SS Isbrytaren which had been built in Sweden in 1881. Plans of that vessel show a more conventional steamer design but sharing the idea of riding up and crushing the ice rather than trying to split it. In 1883, McElhinney had appeared before the parliamentary committee and testified the model for the Northern Light was an excellent one but would be improved by an arrangement for trimming the vessel so it could break harbour ice. The Gazette (Montreal), 8 March 1883.
} 
reported the decision that she was to be built "on the Swedish ice-boat model."75

\section{The Northern Light is extinguished}

The new vessel, the SS Stanley, arrived in Charlottetown on 14 December 1888 and was immediately pressed into service while the Northern Light was laid up in Pictou, pending a decision on her future. ${ }^{76}$ The end of the Northern Light, like that of so many steamships, was inglorious. Last used in the Strait crossing in early 1888 , she was ordered sold by the dominion government in $1889 .{ }^{77}$ Although almost universally condemned for her failure to perform as promised, she did have her supporters. In January 1883 after a rare successful passage, one of those aboard composed a Tennysonian-style ode for the Examiner which read in part:

Right through the mass she goes, Up high the ice she throws,

Staggering at all the blows,

Pounding and crashing.

Oh! How we danced and cheered

When past the dangers feared

When our Island we had neared

As on we came rushing. ${ }^{78}$

When news of the imminent sale of the surplus vessel was made known, the editor of the Examiner expressed regret that the ship "should pass into the hands of speculators and be cut up for old junk." She deserved to be preserved. "Nothing before her was ever before seen; nothing like her will ever be seen again." "W9 Whether sincere or written with tongue in cheek the editorial suggestion was disregarded.

The disposal of the Northern Light was a drawn out process. A paper prepared for the Privy Council reported that her great draft, which made her unsuitable for towing purposes, and her small capacity, which prevented her carrying enough coal to steam any distance, made her unsuitable for any other public purposes. Offered for sale by tender, she attracted eleven bids, but one by one, the successful bidders withdrew their offers and the matter was returned twice more for Privy Council direction before the vessel was sold in 1890 to Messers E. Lantalum \& Co. of Saint John for $\$ 4559 .{ }^{80}$ The Northern Light disappeared from the record until June 1892, when a note appeared in the New Brunswick St. John Daily Telegraph under the title "The Mighty Fallen" informing readers that the machinery was being removed

\footnotetext{
Chignecto Post (Sackville), 28 June1888.

76 Daily Examiner (Charlottetown), 15 December 1888.

77 Daily Examiner (Charlottetown), 17 October 1889.

78 Daily Examiner (Charlottetown), 8 January 1884.

79 Daily Examiner (Charlottetown). 20 May 1889.

80 Morning Chronicle and Commercial and Shipping Gazette (Québec), 12 April 1890; LAC, Privy Council Office Minutes RG2 Series 1 Vol. 430, 433, 444.
} 
from the vessel in preparation to her being turned into a coal barge. ${ }^{81} \mathrm{~A}$ year later the engine-less hulk was burned on the beach at Carleton, across the river from Saint John, in order to recover the iron in the hull. ${ }^{82}$

Sewell's direct involvement with the Northern Light appears to have ended with his unsuccessful bid to take over management of the vessel in 1878. However his efforts to promote his ideas of winter navigation on the St Lawrence continued. Throughout the winter and spring of 1881, he resurrected the campaign for support of the initiative. ${ }^{83}$ Proposing a government-subsidized company to run between Québec and Liverpool, he met with elected officials in both Québec and in Ottawa, as well as with Boards of Trade and other organizations, to promote the idea. While he received some initial indications of support, the financial commitments failed to materialize ${ }^{84}$ The Montreal Herald pointed to past experience with Sewell's scheme: "Experience will be sufficient to prevent the Government from encouraging, in any way, Mr. Sewell's quixotic ideas." ${ }^{95}$ In March 1878, Sewell visited France and England in hopes of obtaining financial support. On his return in July, he stated that he had obtained one third of the necessary support in Paris, but that this foreign involvement had become a barrier to needed English investment. ${ }^{86}$ In September 1881, the journal La Nouvelle-France Revue Bi-Mensuelle published an article by Sewell with the title "De la navigation hibernale sur Le-SaintLaurent" in which his arguments were once again advanced. ${ }^{87}$ In the article, which largely repeated earlier information, Sewell claimed that the Northern Light had exceeded all expectations even when working under the worst possible conditions of management, with incompetent direction and political interference. When Sewell died in February 1882, obituaries identified his passionate pursuit of winter navigation as the guiding force in his life and the building of the Northern Light as his major accomplishment. ${ }^{88}$ However, with several years' experience, decision makers in both Ottawa and Charlottetown held a contrary view of the vessel's effectiveness.

The Northern Light represented a false start for Canadian icebreaker design. Its shortcomings were not addressed through improvements or modification, and it was thus both the beginning and the end of the short line of Canadian icebreaker

\footnotetext{
81 St. John Daily Telegraph, reprinted in Charlottetown Guardian, 28 June 1892.

82 Daily Patriot (Charlottetown), 5 June 1893.

83 See, for example, Montreal Herald and Daily Commercial Gazette, 12 February 1881; Le Courier du Canada, 16 February 1881; Daily Evening Mercury 26 February 1881; Montreal Daily Witness, 1 March 1881.

84 The proposal reached the Privy Council but was referred back to the minister of Marine and Fisheries but no action was taken. Canada Privy Council Order in Council 1881-0451 23 March 1881.

85 Montreal Herald and Daily Commercial Gazette, 4 March 1881.

86 Morning Chronicle and Commercial and Shipping Gazette (Québec), 21 July 1881.

87 E.W. Sewell. "De la navigation hibernale sur Le-Saint-Laurent" La Nouvelle-France 1: 4 (15 September 1881), 49-51, http://numerique.banq.qc.ca/patrimoine/details/52327/2742544?docsearch text=navigation\%20hibernale accessed 3 March 2019.

${ }_{88}$ Morning Chronicle and Shipping Gazette (Québec), 6 February 1882, 1.
} 
design in the nineteenth century. While Baltic icebreakers developed over time to meet the needs of the region better, there is no evidence that any notice was taken of the experience of more than ten years of fighting ice in Northumberland Strait. When the decision was taken to replace the Northern Light, the Canadian government turned for advice to British naval architects. They, in turn, drew on Baltic experience to design "a properly constructed steamer" for Canadian needs. Increasingly, larger and more powerful vessels - the Stanley, the Minto and the Earl Grey - succeeded the Northern Light and were subject to the same challenges and many of the same failures. It was not until the launch of the SS Prince Edward Island in 1915 that anything approaching the "continuous steam communication" envisioned in 1873 was achieved. A gap of just under forty years existed between the launch of the Northern Light and the next Canadian-designed and Canadianbuilt icebreaker. Launched in May 1916, the J.D. Hazen (later sold to the Russian government and renamed the Mikula Selianinovich), ushered in a new period of Canadian icebreaker design and construction. ${ }^{89}$

The legacy of Edwin Sewell and the Northern Light is an almost forgotten story of a man obsessed with winter navigation and the ship that would demonstrate his grand idea. His dream was that a properly constructed vessel could, in fact, maintain effective communications in the ice-bound Gulf of St Lawrence and Northumberland Strait. He conceived, promoted, designed, and built a ship to demonstrate the practicality of his belief. As he foresaw, technology would ultimately triumph over the ice and in time a vessel would be able to provide continuous steam communication between Prince Edward Island and the rest of Canada. Unfortunately Sewell's vessel, the Northern Light, was not that ship.

\footnotetext{
89 George Bolotenko. "The Icebreaker Mikula Selianinovich (1916-1937): To Russia and Back". The Northern Mariner/Le marin du nord 13: 3 (July 2002), 17-42. Bolotenko states that the Hazen was the first icebreaker designed and built in Canada.
} 